\title{
Enhancement of Brassica napus Tolerance to High Saline Conditions by Seed Priming
}

\author{
Panaiotis M. Stassinos ${ }^{1}$, Massimiliano Rossi ${ }^{2}$, Ilaria Borromeo ${ }^{3}$, Concetta Capo ${ }^{1}$, Simone Beninati ${ }^{1}$ \\ and Cinzia Forni $1, *$ (D) \\ 1 Department of Biology, University of Rome Tor Vergata, Via della Ricerca Scientifica, 00133 Rome, Italy; \\ panaiotismario@gmail.com (P.M.S.); capo@uniroma2.it (C.C.); beninati@bio.uniroma2.it (S.B.) \\ 2 PhD Program in Evolutionary Biology and Ecology, Department of Biology, University of Rome Tor Vergata, \\ Via della Ricerca Scientifica, 00133 Rome, Italy; massimiliano87rossi@hotmail.com \\ 3 Department of Physics, University of Rome Tor Vergata, Via della Ricerca Scientifica, 00133 Rome, Italy; \\ ilaria18scv@hotmail.it \\ * Correspondence: forni@uniroma2.it; Tel.: +39-0672594332
}

Citation: Stassinos, P.M.; Rossi, M.; Borromeo, I.; Capo, C.; Beninati, S.; Forni, C. Enhancement of Brassica napus Tolerance to High Saline Conditions by Seed Priming. Plants 2021, 10, 403. https://doi.org/ $10.3390 /$ plants10020403

Academic Editor: Anelia Dobrikova

Received: 1 February 2021

Accepted: 17 February 2021

Published: 20 February 2021

Publisher's Note: MDPI stays neutral with regard to jurisdictional claims in published maps and institutional affiliations.

Copyright: (C) 2021 by the authors. Licensee MDPI, Basel, Switzerland. This article is an open access article distributed under the terms and conditions of the Creative Commons Attribution (CC BY) license (https:/ / creativecommons.org/licenses/by/ $4.0 /)$.

\begin{abstract}
Plants grown in saline soils undergo osmotic and oxidative stresses, affecting growth and photosynthesis and, consequently, the yield. Therefore, the increase in soil salinity is a major threat to crop productivity worldwide. Plant's tolerance can be ameliorated by applying simple methods that induce them to adopt morphological and physiological adjustments to counteract stress. In this work, we evaluated the effects of seed priming on salt stress response in three cultivars of rapeseed (Brassica napus L.) that had different tolerance levels. Seed chemical priming was performed with $2.5 \mathrm{mM}$ spermine (SPM), $5 \mathrm{mM}$ spermidine (SPD), $40 \mathrm{mM} \mathrm{NaCl}$ and $2.5 \mathrm{mM} \mathrm{Ca}\left(\mathrm{NO}_{3}\right)_{2}$. Primed and not primed seeds were sown on saline and not saline (controls) media, and morphological and physiological parameters were determined. Since SPD treatment was effective in reducing salinity negative effects on growth, membrane integrity and photosynthetic pigments, we selected this priming to further investigate plant salt stress response. The positive effects of this seed treatment on growth and physiological responses were evident when primed plants were compared to not primed ones, grown under the same saline conditions. SPD priming ameliorated the tolerance towards saline stress, in a genotype-independent manner, by increasing photosynthetic pigments, proline amounts and antioxidant responses in all cultivars exposed to salt. These results may open new perspectives for crop productivity in the struggle against soil salinization.
\end{abstract}

Keywords: seed priming; spermidine; rapeseed; salt stress; antioxidant activities; proline

\section{Introduction}

The detrimental and growth-limiting effects of abiotic stress are seriously threatening the sustainability of agriculture [1]. Agricultural lands subjected to salinization are increasing worldwide, and the situation is further aggravated by climate change. Therefore, the understanding of how plants respond to salt and co-occurring stresses can play a major role in stabilizing crop performance under such conditions, as well as in the protection of both natural vegetation and crops [2,3].

Brassica napus L. is an extremely important crop being a good producer of oils that can be utilized for both edible oils and biodiesel production [4]. However, this species can be classified as glycophyte, thus with an increasing in soil salinity, growth and yield of this crop can start to decline.

Several tools, such as acclimation [5] and seed priming [6], and the use of plant growthpromoting bacteria (PGPB) $[3,7,8]$ can be utilized to improve plant salt stress tolerance and represent promising strategies. Seed priming is a pre-sowing treatment, consisting of the soaking of the seeds in a priming agent, acting as an elicitor, for a specific period, followed by drying the seeds to avoid radicle emergence. A chemical priming agent can induce 
abiotic stress to seed, stimulating stress responses and possibly inducing a cross-tolerance to different abiotic stress $[9,10]$; in other words, the pre-treatment of seeds with chemical agents, by initiating a mild stress-like cue, allows the creation of a "priming memory", similarly to an acclimation response; consequently, this memory ameliorates the tolerance when the plant is subsequently exposed to different abiotic stress. Priming agents, such as hormones or polyamines (PAs), have been reported to improve the seedling performance in wheat [11] and rice [12]. Such memory acts at phenotypic level [13] and also comprehends epigenetic modifications, changes in gene expression and metabolism, but not changes of DNA sequence.

The profiling of transcriptome shows an increased expression of antioxidant genes, ABA biosynthesis gene, ABA-inducible transcription factors and LEA proteins gene in roots and shoots. Other priming agents (i.e., $\mathrm{H}_{2} \mathrm{O}_{2}, \mathrm{NO}$ and $\mathrm{H}_{2} \mathrm{~S}$ ) showed good results in enhancing abiotic stress tolerance. These compounds increased the regulation of genes responsible for redox cell homeostasis and the synthesis of osmoprotectants [14]. PEG 6000, used as priming agent in rapeseed, enhanced the expression of the pyrroline-5carboxylate synthetase (P5CSA) gene (involved in proline synthesis), the regulation of MYB and the production of transcription factors such as ERF/AP2 and NAC domain-containing proteins [15].

Since the induction of stress tolerance depends on both species and priming agent, a successful application of seed priming needs a screening to detect the best combination of priming agent and plant species. The aim of this work was to seek the possibility to improve salinity tolerance in rapeseed cultivars exposed to high salinity, by evaluating the effectiveness of chemical seed priming as a tool to ameliorate plant survival and fitness. Based on previous results [5] and preliminary tests, three rapeseed cultivars with different levels of tolerance/sensitivity to salt have been selected, i.e., SY Saveo (sensitive), Edimax $\mathrm{CI}$ (intermediate tolerant) and Dynastie (tolerant). Four different priming agents were applied to the seeds $2.5 \mathrm{mM}$ spermine (SPM), $5 \mathrm{mM}$ spermidine (SPD), $40 \mathrm{mM} \mathrm{NaCl}$ and $2.5 \mathrm{mM} \mathrm{Ca}\left(\mathrm{NO}_{3}\right)_{2}$ in order to determine the most effective ones. Primed and not primed seeds were sown in media with different levels of salinity, and seedling growth, representing one of the most delicate phases of plant development, was observed. SPD priming treatment was the most effective; therefore, it was selected to further investigate the responses to salt stress in primed seedlings.

\section{Results}

\subsection{Priming Effects on Seed Germination and Plant Growth in Saline Conditions}

$B$. napus is a species that can be quite sensitive to salinity, particularly during the early phases of development. To improve the performance of the plants in the presence of high levels of salinity, we applied different seed priming agents, i.e., $2.5 \mathrm{mM} \mathrm{SPM}, 5 \mathrm{mM}$ SPD, $40 \mathrm{mM} \mathrm{NaCl}$ and $2.5 \mathrm{mM} \mathrm{Ca}\left(\mathrm{NO}_{3}\right)_{2}$. Seed priming improved the germination rates in both exposed or not to moderate and high salinity (Table 1 ).

The growth of primed seedlings was compared to the not primed ones (controls) exposed or not to salt. Saline conditions reduced the growth of both shoots and roots in a manner related to the increasing salinity of the medium (Tables 2 and 3). A significant reduction in salt negative effect on growth was detected in plants primed with SPD, especially in Edimax and Dynastie cultivars (Table 2). The positive effect of priming was even more evident in roots (Table 3). The most effective agents were SPD and $\mathrm{NaCl}$, which provided the best improvement in root length (SPD in particular) in both low and high saline conditions.

\subsection{Membrane Injury Index and Photosynthetic Pigments}

Salt stress injury can damage the membranes, decrease chlorophylls content and, consequently, photosynthetic activity. Therefore, membrane injury index (MII) and chlorophyll detection can provide useful information about the level of damage caused to the plants. Overall, SPD reduced membrane damage at all salinities (Table 4); a lowering of MII was 
also observed with SPM and $\mathrm{NaCl}$ priming. On the contrary, MII levels increased in plants primed with $\mathrm{Ca}\left(\mathrm{NO}_{3}\right)_{2}$.

Generally, SPD priming increased the chlorophyll amount in the plants, exposed or not to salt (Table 5). While, in calcium nitrate primed samples, the chlorophylls were significantly lower than the controls of Sy Saveo and Dynastie grown at 40 and $160 \mathrm{mM}$ salt concentrations (Table 5). Carotenoid amount was higher in plants primed with SPD, in particular at $160 \mathrm{mM} \mathrm{NaCl}$ (Table 6). Vice versa, $\mathrm{Ca}\left(\mathrm{NO}_{3}\right)_{2}$ priming decreased the amount of carotenoids in all cultivars at high salt concentration (Table 6).

Table 1. Effect of different priming agents on seed germination (\%) of rapeseed cultivars exposed to different saline conditions: $0 \mathrm{mM} \mathrm{NaCl}(\mathrm{C}), 40 \mathrm{mM} \mathrm{NaCl}(40), 80 \mathrm{mM} \mathrm{NaCl}(80), 160 \mathrm{mM} \mathrm{NaCl}$ (160). Data are expressed as means $\pm \mathrm{SE}$ $(n=3)$. Mean values in the column marked by different letters are significantly different within the same group $(p \leq 0.05$; ANOVA and Tukey-Kramer test). Significant differences between groups are reported as ${ }^{*} p<0.05 ;{ }^{* *} p<0.01 ;{ }^{* * *} p<0.001$.

\begin{tabular}{|c|c|c|c|c|c|}
\hline \multicolumn{6}{|c|}{ Germination (\%) } \\
\hline Cultivars & $40 \mathrm{mM} \mathrm{NaCl}$ & $5 \mathrm{mM}$ SPD & $2.5 \mathrm{mM}$ SPM & $2.5 \mathrm{mM} \mathrm{Ca}\left(\mathrm{NO}_{3}\right)_{2}$ & No Priming \\
\hline Sy Saveo C & $98 \pm 1 \mathrm{a}$ & $100 a^{*}$ & $98 \pm 0.88 \mathrm{a}$ & $98 \pm 0.88 \mathrm{a}$ & $95 \pm 0.33 \mathrm{a}$ \\
\hline Sy Saveo 40 & $96 \pm 0.62 \mathrm{ab}^{* * *}$ & $99 \pm 1.13 \mathrm{a}^{* * *}$ & $97 \pm 0.13 a^{* * *}$ & $97 \pm 0.1 \mathrm{a}^{* * *}$ & $8 \pm 0.95 b$ \\
\hline Sy Saveo 80 & $94 \pm 0.6 \mathrm{ab}^{* * *}$ & $98 \pm 0.88 a^{* * *}$ & $96 \pm 0.7 a^{* * *}$ & $87 \pm 1.15 b$ & $84 \pm 0.66 b$ \\
\hline Sy Saveo 160 & $93 \pm 0.33 b^{* * *}$ & $92 \pm 1 b^{* * *}$ & $91 \pm 0.88 b^{* * *}$ & $85 \pm 1.15 b^{* *}$ & $77 \pm 1.45 c$ \\
\hline Edimax C & $98 \pm 1.1 \mathrm{a}^{* *}$ & $93 \pm 0.57 \mathrm{a}$ & $93 \pm 0.63 \mathrm{a}$ & $98 \pm 1.58 a^{* *}$ & $91 \pm 1 \mathrm{a}$ \\
\hline Edimax 40 & $96 \pm 0.65 a^{* *}$ & $88 \pm 1 \mathrm{a}$ & $89 \pm 1 \mathrm{a}$ & $94 \pm 0.56 \mathrm{ab}^{*}$ & $88 \pm 1 \mathrm{a}$ \\
\hline Edimax 80 & $91 \pm 1 b^{* * *}$ & $88 \pm 1 \mathrm{a}^{* *}$ & $84 \pm 0.5 b$ & $93 \pm 0.16 \mathrm{ab}^{* * *}$ & $82 \pm 1.1 b$ \\
\hline Edimax 160 & $90 \pm 0.24 b^{* * *}$ & $79 \pm 1.13 b$ & $75 \pm 1.07 c^{*}$ & $91 \pm 1.1 b^{* * *}$ & $80 \pm 1.82 b$ \\
\hline Dynastie C & $100 a^{* *}$ & $100 a^{* *}$ & $100 a^{* *}$ & $100 a^{* *}$ & $96 \pm 0.53 a$ \\
\hline Dynastie 40 & $99 \pm 1 \mathrm{ab}$ & $98 \pm 1 \mathrm{a}$ & $95 \pm 1.06 b$ & $99 \pm 1 \mathrm{a}$ & $95 \pm 1.23 \mathrm{a}$ \\
\hline Dynastie 80 & $97 \pm 0.33 b^{* *}$ & $97 \pm 0.19 a^{* *}$ & $94 \pm 0.63 b$ & $96 \pm 0.52 b^{* *}$ & $93 \pm 0.47 a$ \\
\hline Dynastie 160 & $93 \pm 1.47 c^{* * *}$ & $90 \pm 1.85 b^{* * *}$ & $80 \pm 2.13 c$ & $90 \pm 1.82 c^{* * *}$ & $81 \pm 1 b$ \\
\hline
\end{tabular}

Table 2. Effect of different priming agents on shoot length $(\mathrm{cm})$ of rapeseed cultivars exposed to different saline conditions: $0 \mathrm{mM} \mathrm{NaCl}(\mathrm{C}), 40 \mathrm{mM} \mathrm{NaCl}(40), 80 \mathrm{mM} \mathrm{NaCl}(80), 160 \mathrm{mM} \mathrm{NaCl}(160)$. Data are expressed as means $\pm \mathrm{SE}(n=8)$. Mean values in the column marked by different letters are significantly different within the same group ( $p \leq 0.05$; ANOVA and Tukey-Kramer test). Significant differences between groups are reported as ${ }^{*} p<0.05 ;{ }^{* *} p<0.01 ;{ }^{* * *} p<0.001$.

\begin{tabular}{|c|c|c|c|c|c|}
\hline \multicolumn{6}{|c|}{ Shoot Length $(\mathrm{cm})$} \\
\hline Cultivars & $40 \mathrm{mM} \mathrm{NaCl}$ & $5 \mathrm{mM}$ SPD & $2.5 \mathrm{mM} \mathrm{SPM}$ & $2.5 \mathrm{mM} \mathrm{Ca}\left(\mathrm{NO}_{3}\right)_{2}$ & No Priming \\
\hline Sy Saveo C & $8.4 \pm 0.3 \mathrm{a}$ & $9.8 \pm 0.3 a^{*}$ & $7.5 \pm 0.3 \mathrm{a}$ & $8.5 \pm 0.3 \mathrm{a}$ & $8.2 \pm 0.4 \mathrm{a}$ \\
\hline Sy Saveo 40 & $6.3 \pm 0.2 b$ & $5.9 \pm 0.2 b$ & $6.1 \pm 0.5 \mathrm{a}$ & $6.4 \pm 0.2 \mathrm{~b}$ & $5.6 \pm 0.2 b$ \\
\hline Sy Saveo 80 & $5.3 \pm 0.2 c$ & $4.8 \pm 0.2 \mathrm{~b}$ & $3.8 \pm 0.4 b^{*}$ & $5.6 \pm 0.2 b$ & $4.9 \pm 0.2 b$ \\
\hline Sy Saveo 160 & $1.6 \pm 0.1 \mathrm{~d}$ & $1.9 \pm 0.1 \mathrm{c}$ & $1.9 \pm 0.1 \mathrm{c}$ & $1.8 \pm 0.2 \mathrm{c}$ & $1.4 \pm 0.1 \mathrm{~d}$ \\
\hline Edimax C & $8.7 \pm 0.3 \mathrm{a}$ & $9.7 \pm 0.3 \mathrm{a}^{* *}$ & $8 \pm 0.3 a$ & $8.2 \pm 0.2 \mathrm{a}$ & $8.5 \pm 0.3 \mathrm{a}$ \\
\hline Edimax 40 & $6.5 \pm 0.2 b$ & $6.1 \pm 0.1 \mathrm{~b}$ & $6.9 \pm 0.4 b^{*}$ & $6.1 \pm 0.2 b$ & $5.8 \pm 0.2 b$ \\
\hline Edimax 80 & $5.4 \pm 0.1 \mathrm{c}$ & $5.8 \pm 0.3 b^{* *}$ & $4.3 \pm 0.4 \mathrm{c}$ & $5.1 \pm 0.3 b$ & $4.7 \pm 0.1 \mathrm{c}$ \\
\hline Edimax 160 & $2.3 \pm 0.3 \mathrm{~d}^{*}$ & $2.1 \pm 0.1 \mathrm{c}$ & $2 \pm 0.1 \mathrm{~d}$ & $2.3 \pm 0.3 \mathrm{c}$ & $1.6 \pm 0.2 \mathrm{~d}$ \\
\hline Dynastie C & $9.2 \pm 0.2 \mathrm{a}$ & $10.4 \pm 0.3 a^{* *}$ & $9 \pm 0.4 \mathrm{a}$ & $8.4 \pm 0.2 \mathrm{a}$ & $8.9 \pm 0.2 \mathrm{a}$ \\
\hline Dynastie 40 & $7.1 \pm 0.2 b$ & $7.5 \pm 0.3 b^{* *}$ & $7.8 \pm 0.3 b^{* *}$ & $6.6 \pm 0.3 b$ & $6.4 \pm 0.1 \mathrm{~b}$ \\
\hline Dynastie 80 & $5.5 \pm 0.2 c$ & $6.2 \pm 0.3 c^{* *}$ & $5 \pm 0.2 c$ & $5.2 \pm 0.2 c$ & $4.9 \pm 0.1 \mathrm{c}$ \\
\hline Dynastie 160 & $2.7 \pm 0.3 \mathrm{~d}$ & $3 \pm 0.2 \mathrm{~d}^{*}$ & $2.4 \pm 0.2 \mathrm{~d}$ & $2.6 \pm 0.2 \mathrm{~d}$ & $2.2 \pm 0.2 \mathrm{~d}$ \\
\hline
\end{tabular}


Table 3. Effect of different priming agents on root length $(\mathrm{cm})$ of rapeseed cultivars exposed to different saline conditions: 0 $\mathrm{mM} \mathrm{NaCl}(\mathrm{C}), 40 \mathrm{mM} \mathrm{NaCl}(40), 80 \mathrm{mM} \mathrm{NaCl}(80), 160 \mathrm{mM} \mathrm{NaCl}(160)$. Data are expressed as means $\pm \mathrm{SE}(n=8)$. Mean values in the column marked by different letters are significantly different within the same group ( $p \leq 0.05$; ANOVA and Tukey-Kramer test). Significant differences between groups are reported as ${ }^{*} p<0.05 ;{ }^{* *} p<0.01 ;{ }^{* *} p<0.001$.

\begin{tabular}{|c|c|c|c|c|c|}
\hline \multicolumn{6}{|c|}{ Root Length (cm) } \\
\hline Cultivars & $40 \mathrm{mM} \mathrm{NaCl}$ & $5 \mathrm{mM}$ SPD & $2.5 \mathrm{mM}$ SPM & $2.5 \mathrm{mM} \mathrm{Ca}\left(\mathrm{NO}_{3}\right)_{2}$ & No Priming \\
\hline Sy Saveo C & $10.3 \pm 0.4 \mathrm{a}^{* * *}$ & $10.6 \pm 0.4 \mathrm{a}^{* * *}$ & $9.3 \pm 0.7 \mathrm{a}^{* * *}$ & $11.5 \pm 0.3 \mathrm{a}^{* * *}$ & $7.3 \pm 0.6 \mathrm{a}$ \\
\hline Sy Saveo 40 & $8.6 \pm 0.3 b^{* * *}$ & $8.1 \pm 0.4 b^{* * *}$ & $7.7 \pm 0.7 b^{* * *}$ & $7 \pm 0.3 b^{* *}$ & $5.6 \pm 0.6 \mathrm{~b}$ \\
\hline Sy Saveo 80 & $5.6 \pm 0.5 c^{* *}$ & $7.1 \pm 0.6 \mathrm{~b}$ & $4.8 \pm 0.7 c^{* *}$ & $5.5 \pm 0.4 c^{* *}$ & $7.1 \pm 0.4 \mathrm{a}$ \\
\hline Sy Saveo 160 & $4.4 \pm 0.2 \mathrm{~d}^{* * *}$ & $5.8 \pm 0.2 c^{* * *}$ & $1.9 \pm 0.2 \mathrm{~d}$ & $3.5 \pm 0.2 \mathrm{~d}^{* *}$ & $1.8 \pm 0.2 \mathrm{c}$ \\
\hline Edimax C & $10.6 \pm 0.3 a^{* *}$ & $12.3 \pm 0.5 \mathrm{a}^{* * *}$ & $10.7 \pm 0.5 \mathrm{a}^{* *}$ & $9.6 \pm 0.3 \mathrm{a}$ & $8.9 \pm 0.3 \mathrm{a}$ \\
\hline Edimax 40 & $9.0 \pm 0.3 b^{* *}$ & $8.8 \pm 0.3 b^{* *}$ & $8.6 \pm 0.5 b^{*}$ & $8.5 \pm 0.3 b^{*}$ & $7.5 \pm 0.2 \mathrm{~b}$ \\
\hline Edimax 80 & $6.2 \pm 0.4 \mathrm{c}$ & $6.9 \pm 0.4 c^{*}$ & $6.1 \pm 0.4 \mathrm{c}$ & $5.1 \pm 0.3 c^{*}$ & $6.2 \pm 0.2 c$ \\
\hline Edimax 160 & $4.9 \pm 0.2 \mathrm{~d}^{* * *}$ & $6.3 \pm 0.3 c^{* * *}$ & $2.6 \pm 0.3 \mathrm{~d}$ & $3.8 \pm 0.3 \mathrm{~d}^{*}$ & $2.2 \pm 0.3 \mathrm{~d}$ \\
\hline Dynastie C & $10.8 \pm 0.3 a^{*}$ & $13.6 \pm 0.2 \mathrm{a}^{* * *}$ & $11.3 \pm 0.3 a^{* *}$ & $9.2 \pm 0.2 \mathrm{a}$ & $9.8 \pm 0.3 \mathrm{a}$ \\
\hline Dynastie 40 & $9.3 \pm 0.3 b^{* *}$ & $9.7 \pm 0.3 b^{* *}$ & $9.8 \pm 0.3 b^{* *}$ & $8.9 \pm 0.2 a^{*}$ & $7.9 \pm 0.2 \mathrm{~b}$ \\
\hline Dynastie 80 & $6.5 \pm 0.3 c$ & $8.3 \pm 0.3 c^{* *}$ & $7.4 \pm 0.2 c^{*}$ & $5.5 \pm 0.3 b^{*}$ & $6.6 \pm 0.2 c$ \\
\hline Dynastie 160 & $5.4 \pm 0.2 \mathrm{~d}^{* * *}$ & $7.1 \pm 0.2 \mathrm{~d}^{* * *}$ & $4.6 \pm 0.3 \mathrm{~d}^{* *}$ & $2.5 \pm 0.3 c$ & $2.7 \pm 0.2 \mathrm{~d}$ \\
\hline
\end{tabular}

Table 4. Effect of different priming agents on membrane injury index (\%) of rapeseed cultivars exposed to different saline conditions: $0 \mathrm{mM} \mathrm{NaCl}(\mathrm{C}), 40 \mathrm{mM} \mathrm{NaCl}(40), 80 \mathrm{mM} \mathrm{NaCl}(80), 160 \mathrm{mM} \mathrm{NaCl}$ (160). Data are expressed as means $\pm \mathrm{SE}$ $(n=8)$. Mean values in the column marked by different letters are significantly different within the same group $(p \leq 0.05$; ANOVA and Tukey-Kramer test). Significant differences between groups are reported as ${ }^{*} p<0.05 ;{ }^{* *} p<0.01 ;{ }^{* * *} p<0.001$.

\begin{tabular}{|c|c|c|c|c|c|}
\hline \multicolumn{6}{|c|}{ Membrane Injury Index (MII \%) } \\
\hline Cultivars & $40 \mathrm{mM} \mathrm{NaCl}$ & $5 \mathrm{mM}$ SPD & $2.5 \mathrm{mM}$ SPM & $2.5 \mathrm{mM} \mathrm{Ca}\left(\mathrm{NO}_{3}\right)_{2}$ & No Priming \\
\hline Sy Saveo C & $18 \pm 0.2 \mathrm{a}$ & $15 \pm 0.87 a^{* *}$ & $19 \pm 0.33 \mathrm{a}$ & $21 \pm 0.3 \mathrm{a} *$ & $19 \pm 0.47 \mathrm{a}$ \\
\hline Sy Saveo 40 & $25 \pm 0.24 b^{* *}$ & $26 \pm 1.53 b^{* * *}$ & $33 \pm 1.46 b$ & $30 \pm 0.96 b^{*}$ & $33 \pm 0.29 b$ \\
\hline Sy Saveo 80 & $43 \pm 0.88 c^{*}$ & $33 \pm 1.11 c^{* * *}$ & $43 \pm 0.1 c^{*}$ & $51 \pm 1.35 c^{* *}$ & $46 \pm 1.13 c$ \\
\hline Sy Saveo 160 & $46 \pm 0.41 c^{* * *}$ & $40 \pm 0.74 \mathrm{~d}^{* * *}$ & $48 \pm 0.26 \mathrm{~d}^{* * *}$ & $61 \pm 1.91 \mathrm{~d}^{* *}$ & $55 \pm 2.12 \mathrm{~d}$ \\
\hline Edimax C & $18 \pm 1.31 \mathrm{a}$ & $13 \pm 1.84 \mathrm{a}^{* *}$ & $17 \pm 0.13 \mathrm{a}$ & $24 \pm 1.41 \mathrm{a}^{* *}$ & $18 \pm 1.38 \mathrm{a}$ \\
\hline Edimax 40 & $24 \pm 1.05 b^{* *}$ & $23 \pm 0.92 b^{* *}$ & $31 \pm 0.94 b$ * & $32 \pm 1.2 b^{* *}$ & $28 \pm 1.06 b$ \\
\hline Edimax 80 & $44 \pm 0.82 \mathrm{c}^{* *}$ & $31 \pm 0.31 \mathrm{c}^{* * *}$ & $41 \pm 0.29 c^{*}$ & $49 \pm 1.35 c^{* * *}$ & $39 \pm 1.09 c$ \\
\hline Edimax 160 & $55 \pm 0.21 \mathrm{~d}$ & $43 \pm 2.09 \mathrm{~d}^{* * *}$ & $46 \pm 0.11 \mathrm{~d}^{* * *}$ & $63 \pm 3.27 d^{* * *}$ & $55 \pm 2.33 \mathrm{~d}$ \\
\hline Dynastie C & $18 \pm 1.53 \mathrm{a}$ & $13 \pm 1.25 \mathrm{a}^{* *}$ & $20 \pm 0.24 \mathrm{a}$ & $25 \pm 1.18 \mathrm{a}^{*}$ & $20 \pm 0.91 \mathrm{a}$ \\
\hline Dynastie 40 & $25 \pm 0.86 b^{* *}$ & $20 \pm 0.14 b^{* * *}$ & $29 \pm 0.89 \mathrm{~b}$ & $33 \pm 0.23 b^{*}$ & $29 \pm 1.2 b$ \\
\hline Dynastie 80 & $43 \pm 0.4 c^{* * *}$ & $23 \pm 0.38 b^{* * *}$ & $40 \pm 0.99 c^{* *}$ & $55 \pm 0.94 \mathrm{c}^{* * *}$ & $36 \pm 0.3 c$ \\
\hline Dynastie 160 & $56 \pm 1.01 \mathrm{~d}^{* *}$ & $32 \pm 0.9 c^{* * *}$ & $47 \pm 1.31 \mathrm{~d}^{*}$ & $61 \pm 1.07 \mathrm{~d}^{* * *}$ & $51 \pm 1.12 \mathrm{~d}$ \\
\hline
\end{tabular}


Table 5. Effect of different priming agents on total chlorophyll content $\left(\mu \mathrm{g} \mathrm{g} \mathrm{FW}^{-1}\right)$ of rapeseed cultivars exposed to different saline conditions: $0 \mathrm{mM} \mathrm{NaCl}(\mathrm{C}), 40 \mathrm{mM} \mathrm{NaCl}(40), 80 \mathrm{mM} \mathrm{NaCl}(80), 160 \mathrm{mM} \mathrm{NaCl}(160)$. Data are expressed as means $\pm \mathrm{SE}(n=8)$. Mean values in the column marked by different letters are significantly different within the same group $\left(p \leq 0.05\right.$; ANOVA and Tukey-Kramer test). Significant differences between groups are reported as ${ }^{*} p<0.05 ;{ }^{* *} p<0.01$; $* * * p<0.001$.

\begin{tabular}{|c|c|c|c|c|c|}
\hline \multicolumn{6}{|c|}{ Chlorophylls ( $\mu$ g g FW ${ }^{-1}$ ) } \\
\hline Cultivars & $40 \mathrm{mM} \mathrm{NaCl}$ & $5 \mathrm{mM}$ SPD & $2.5 \mathrm{mM}$ SPM & $2.5 \mathrm{mM} \mathrm{Ca}\left(\mathrm{NO}_{3}\right)_{2}$ & No Priming \\
\hline Sy Saveo C & $91.4 \pm 0.87 \mathrm{a}$ & $95.54 \pm 0.73 \mathrm{a}$ & $91.2 \pm 1.54 \mathrm{a}$ & $89.02 \pm 1.18 \mathrm{a}$ & $91.33 \pm 0.8 a$ \\
\hline Sy Saveo 40 & $93.14 \pm 1.17 \mathrm{a}$ & $94.74 \pm 1.42 \mathrm{a}$ & $95.8 \pm 0.97 \mathrm{a}$ & $90.31 \pm 0.42 \mathrm{a}^{*}$ & $94.04 \pm 0.95 \mathrm{a}$ \\
\hline Sy Saveo 80 & $93.82 \pm 1.09 \mathrm{a}$ & $98.59 \pm 1.47 \mathrm{a}^{* * *}$ & $98.03 \pm 2.03 b^{* *}$ & $92.46 \pm 1.23 \mathrm{a}$ & $92.93 \pm 1.36 \mathrm{a}$ \\
\hline Sy Saveo 160 & $91.63 \pm 0.9 \mathrm{a}^{*}$ & $102 \pm 0.36 b^{* * *}$ & $99.11 \pm 1.27 \mathrm{bc} * *$ & $90.38 \pm 0.66 a^{*}$ & $94.3 \pm 1.16 \mathrm{a}$ \\
\hline Edimax C & $93.82 \pm 0.51 \mathrm{a}$ & $95.95 \pm 0.65 a^{*}$ & $94.24 \pm 1.24 \mathrm{a}$ & $91.38 \pm 0.88 \mathrm{a}$ & $93.25 \pm 0.96 \mathrm{a}$ \\
\hline Edimax 40 & $95.65 \pm 1.22 \mathrm{a}$ & $101 \pm 0.98 \mathrm{bd}^{* *}$ & $96.89 \pm 1.35 \mathrm{a}$ & $93.17 \pm 0.82 \mathrm{ab}$ & $95.76 \pm 1.43 \mathrm{a}$ \\
\hline Edimax 80 & $93.89 \pm 0.54 \mathrm{a}$ & $103.9 \pm 0.9 \mathrm{bc}^{* * *}$ & $99.04 \pm 1.66 \mathrm{a}^{* *}$ & $94.77 \pm 0.71 \mathrm{~b}$ & $94.06 \pm 0.77 \mathrm{a}$ \\
\hline Edimax 160 & $93.23 \pm 0.93 \mathrm{a} *$ & $104.15 \pm 1 \mathrm{~cd}^{* * *}$ & $100 \pm 1.22 \mathrm{a}^{*}$ & $94.41 \pm 0.62 \mathrm{ab}$ & $96.38 \pm 0.83 a$ \\
\hline Dynastie C & $97.39 \pm 0.45 a$ & $98.47 \pm 0.55 a$ & $98.35 \pm 0.72 \mathrm{a}$ & $95.77 \pm 0.46 \mathrm{a}$ & $98.46 \pm 0.54 \mathrm{a}$ \\
\hline Dynastie 40 & $98.28 \pm 0.48 a$ & $105.8 \pm 0.6 \mathrm{bc} * *$ & $101.44 \pm 0.98 \mathrm{a}$ & $95.86 \pm 0.57 a^{*}$ & $98.84 \pm 1.42 \mathrm{a}$ \\
\hline Dynastie 80 & $97.31 \pm 0.9 \mathrm{a}$ & $107.6 \pm 1.4 \mathrm{~cd}^{* * *}$ & $99.87 \pm 0.62 \mathrm{a}$ & $96.08 \pm 1.06 \mathrm{a}$ & $97.56 \pm 0.87 \mathrm{a}$ \\
\hline Dynastie 160 & $97.37 \pm 0.72 a^{*}$ & $107.25 \pm 0.15 \mathrm{~d}^{* *}$ & $103.17 \pm 0.82 \mathrm{a}$ & $96.5 \pm 0.24 \mathrm{a}^{* *}$ & $101.15 \pm 1 \mathrm{a}$ \\
\hline
\end{tabular}

Table 6. Effect of different priming agents on total carotenoid content ( $\mu \mathrm{g} \mathrm{g} \mathrm{FW}{ }^{-1}$ ) of rapeseed cultivars exposed to different saline conditions: $0 \mathrm{mM} \mathrm{NaCl}(\mathrm{C}), 40 \mathrm{mM} \mathrm{NaCl}(40), 80 \mathrm{mM} \mathrm{NaCl}(80), 160 \mathrm{mM} \mathrm{NaCl}(160)$. Data are expressed as means $\pm \mathrm{SE}(n=8)$. Mean values in the column marked by different letters are significantly different within the same group $\left(p \leq 0.05\right.$; ANOVA and Tukey-Kramer test). Significant differences between groups are reported as ${ }^{*} p<0.05 ;{ }^{* *} p<0.01$; $* * * p<0.001$.

\begin{tabular}{|c|c|c|c|c|c|}
\hline \multicolumn{6}{|c|}{ Carotenoids ( $\mu \mathrm{g}$ g FW $\left.\mathrm{FW}^{-1}\right)$} \\
\hline Cultivars & $40 \mathrm{mM} \mathrm{NaCl}$ & $5 \mathrm{mM}$ SPD & $2.5 \mathrm{mM}$ SPM & $2.5 \mathrm{mM} \mathrm{Ca}\left(\mathrm{NO}_{3}\right)_{2}$ & No Priming \\
\hline Sy Saveo C & $38.36 \pm 0.11 \mathrm{a}$ & $38.1 \pm 0.16 \mathrm{a}$ & $37.7 \pm 0.16 \mathrm{a}$ & $37.71 \pm 0.07 \mathrm{a}$ & $37.93 \pm 0.08 a$ \\
\hline Sy Saveo 40 & $38.31 \pm 0.12 \mathrm{a}$ & $38.54 \pm 0.06 \mathrm{a}$ & $38.05 \pm 0.2 \mathrm{a}$ & $38.06 \pm 0.17 \mathrm{a}$ & $38.17 \pm 0.17 \mathrm{a}$ \\
\hline Sy Saveo 80 & $37.94 \pm 0.13 a$ & $38.9 \pm 0.14 b$ & $38.3 \pm 0.14 \mathrm{a}$ & $37.18 \pm 0.23 b$ * & $38.2 \pm 0.18 \mathrm{a}$ \\
\hline Sy Saveo 160 & $37.85 \pm 0.1 \mathrm{a}$ & $39.05 \pm 0.11 c^{* *}$ & $38.73 \pm 0.18 b^{*}$ & $36.48 \pm 0.18 c^{*}$ & $37.83 \pm 0.08 \mathrm{a}$ \\
\hline Edimax C & $38.56 \pm 0.12 \mathrm{a}$ & $38.85 \pm 0.14 \mathrm{a}$ & $38.38 \pm 0.17 \mathrm{a}$ & $38.06 \pm 0.17 \mathrm{ab}$ & $38.22 \pm 0.17 \mathrm{a}$ \\
\hline Edimax 40 & $38.54 \pm 0.06 \mathrm{a}$ & $38.8 \pm 0.17 \mathrm{a}$ & $38.51 \pm 0.1 \mathrm{ab}$ & $38.44 \pm 0.06 \mathrm{~b}$ & $38.18 \pm 0.27 \mathrm{a}$ \\
\hline Edimax 80 & $38.5 \pm 0.18 \mathrm{a}$ & $39.2 \pm 0.16 a^{*}$ & $38.65 \pm 0.18 \mathrm{ab}$ & $37.77 \pm 0.09 \mathrm{ca}$ * & $38.55 \pm 0.22 \mathrm{a}$ \\
\hline Edimax 160 & $38.36 \pm 0.09 a$ & $39.29 \pm 0.31 a^{*}$ & $39.26 \pm 0.21 b^{*}$ & $36.89 \pm 0.2 \mathrm{~d}^{*}$ & $38.16 \pm 0.17 a$ \\
\hline Dynastie C & $39.19 \pm 0.11 \mathrm{a}$ & $39.37 \pm 0.06 \mathrm{ab}$ & $38.67 \pm 0.15 \mathrm{a}$ & $38.66 \pm 0.03 \mathrm{a}$ & $39.15 \pm 0.12 \mathrm{a}$ \\
\hline Dynastie 40 & $38.96 \pm 0.14 \mathrm{a}$ & $39.25 \pm 0.11 \mathrm{a}$ & $38.68 \pm 0.09 a$ & $38.7 \pm 0.12 \mathrm{a}$ & $39.04 \pm 0.07 \mathrm{a}$ \\
\hline Dynastie 80 & $38.97 \pm 0.16 \mathrm{a}$ & $39.52 \pm 0.18 \mathrm{ab}$ & $39.22 \pm 0.07 \mathrm{bc}$ & $38.57 \pm 0.09 a$ & $39.32 \pm 0.19 a$ \\
\hline Dynastie 160 & $37.99 \pm 022 b$ & $39.84 \pm 0.09 b^{*}$ & $39.46 \pm 0.04 c$ & $37.5 \pm 0.09 b^{* *}$ & $39.08 \pm 0.03 \mathrm{a}$ \\
\hline
\end{tabular}

\subsection{Effects of SPD Priming on Antioxidant and Osmotic Responses}

The priming with SPD was the most effective in all cultivars, showing genotype independence; therefore, we decided to further investigate the effect of this PA in counteracting the toxicity of salt, especially in eliciting antioxidant and osmotic responses of the plants. The latter may represent the key to understanding some of the effects of SPD priming. The synthesis of phenolics and antioxidant enzyme activities counteract the overproduction of 
ROS, consequent to salt exposure. An increase in the quantity of phenolic compounds was detected in the primed cultivars with respect to the not primed controls with significant differences detected at the different salinity levels (Figure 1). The increase of the synthesis of phenolic compounds was related to PAL activity (Figure 2) that showed an enhancement in primed plants, particularly in Dynastie (Figure 2).

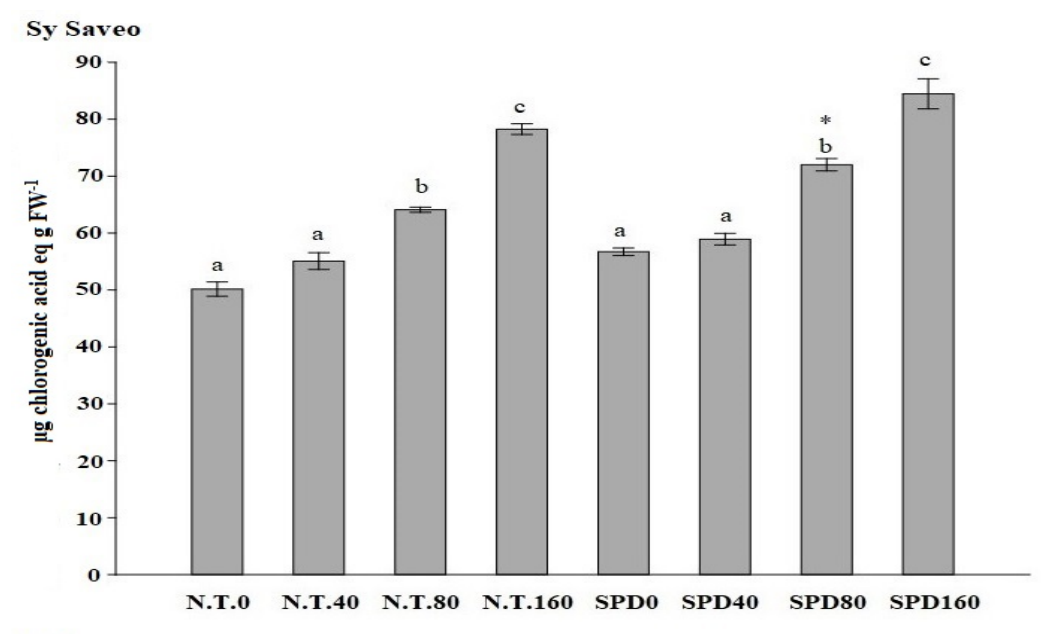

N.T. $=$ not treated SPD $=$ spermidine $0=0 \mathrm{mM} \mathrm{NaCl}$ $40=40 \mathrm{mM} \mathrm{NaCl}$ $\mathbf{8 0}=\mathbf{8 0} \mathbf{~ m M ~ N a C l}$ $160=160 \mathrm{mM} \mathrm{NaCl}$
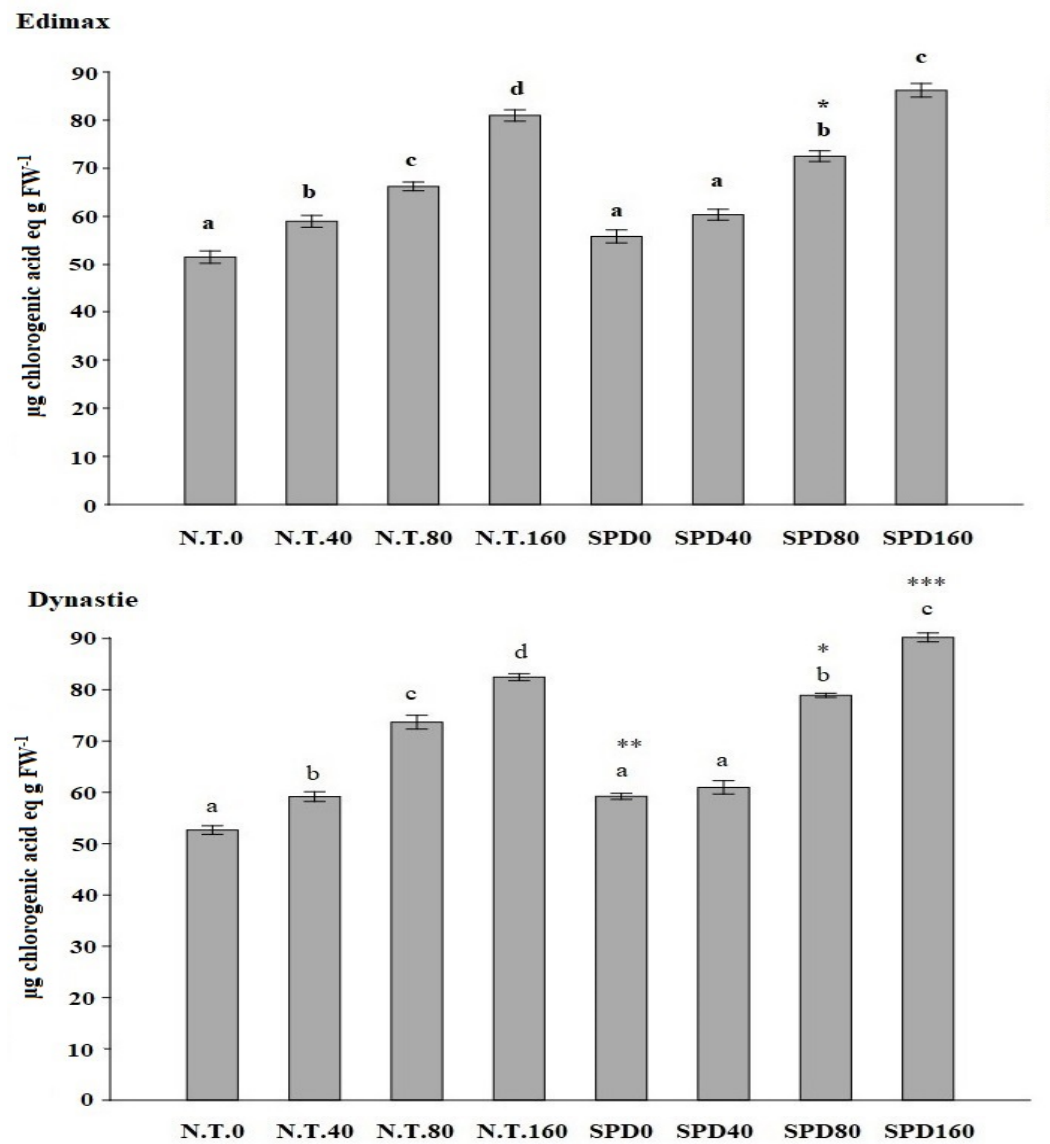

N.T. $=$ not treated SPD = spermidine $40=40 \mathrm{mM}$ ( $80=80 \mathrm{mM} \mathrm{NaCl}$ $160=160 \mathrm{mM} \mathrm{NaCl}$

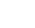



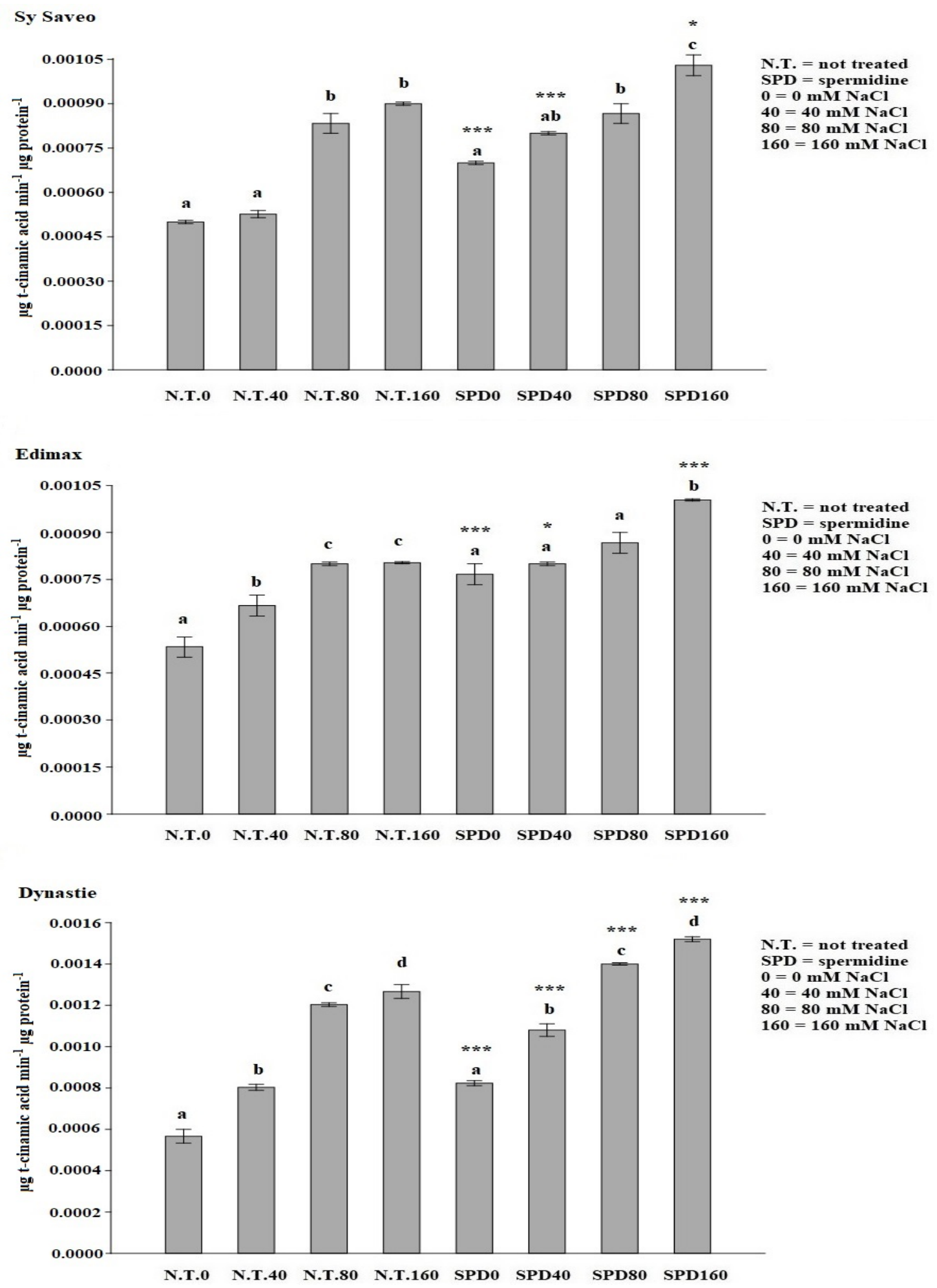

Figure 2. Effect of spermidine priming on PAL activity of rapeseed cultivars exposed to saline conditions. Data are expressed as means $\pm S E(n=3)$. Mean values in the column marked by different letters are significantly different within the same group $\left(p \leq 0.05\right.$; ANOVA and Tukey-Kramer test). Significant differences between groups are reported as ${ }^{*} p<0.05 ;{ }^{* * *} p<0.001$.

The enzymatic antioxidant response was evaluated by determining SOD activity. The latter increased in primed plants with respect to the not primed ones at all $\mathrm{NaCl}$ concentrations (Figure 3). Dynastie samples showed small differences in activity between primed and not primed plants (Figure 3). 

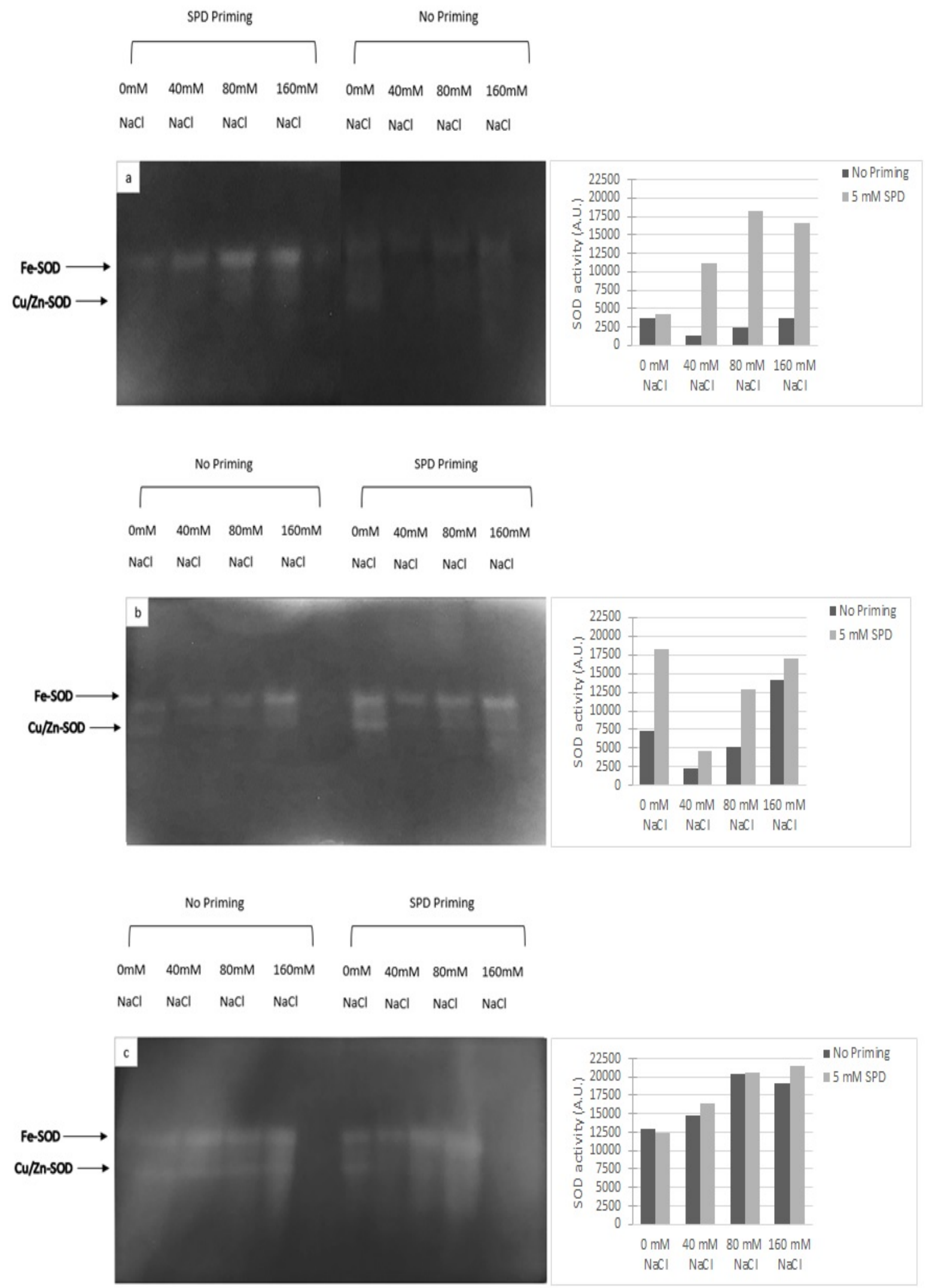

Figure 3. Effect of spermidine priming on SOD activity of rapeseed cultivars exposed to saline conditions ((a): Sy Saveo, (b): Edimax, (c): Dynastie).

Moreover, SPD priming induced the synthesis of the osmolyte proline; its amount enhanced significantly in all samples exposed to salt (Figure 4). 

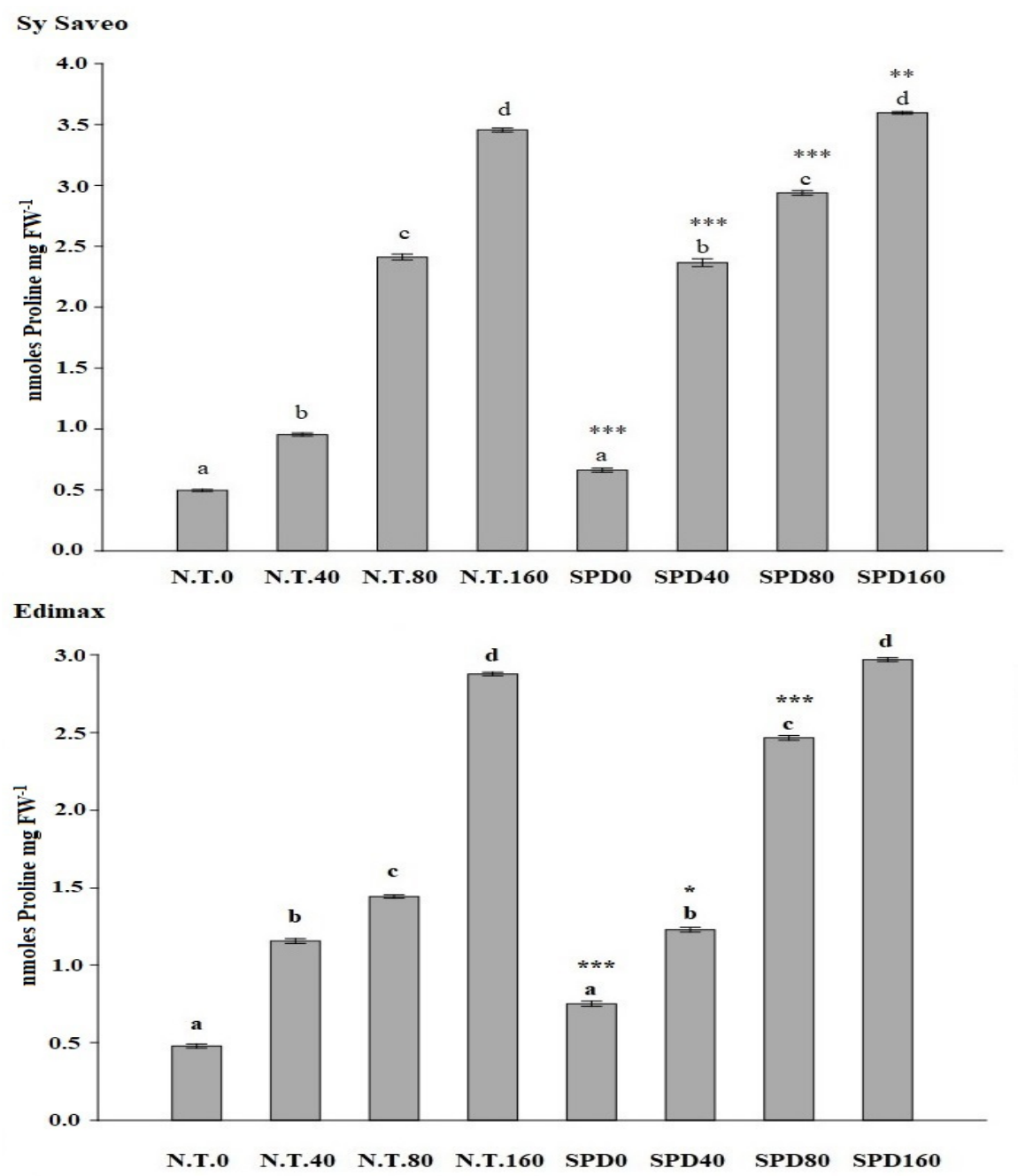

N.T. $=$ not treated SPD $=$ spermidine $0=0 \mathrm{mM}$ NaCl

$40=40 \mathrm{mM} \mathrm{NaCl}$

$160=160$ m $\mathrm{NaCl}$

$160=160 \mathrm{mM} \mathrm{NaCl}$

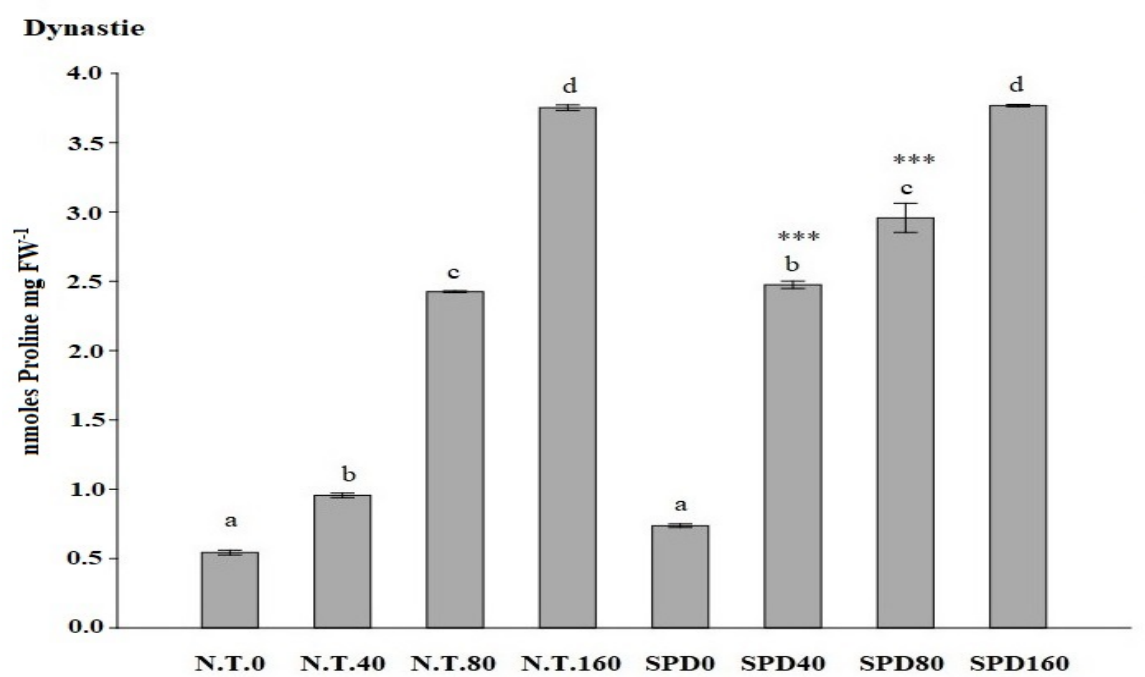

N.T. $=$ not treated SPD $=$ spermidine $0=0 \mathrm{mM} \mathrm{NaCl}$ $40=40 \mathrm{mM} \mathrm{NaCl}$ $\mathbf{8 0}=\mathbf{8 0} \mathbf{m M} \mathrm{NaCl}$ $160=160 \mathrm{mM} \mathrm{NaCl}$

Figure 4. Effect of spermidine priming on proline amount of rapeseed cultivars exposed to saline conditions. Data are expressed as means $\pm \mathrm{SE}(n=3)$. Mean values in the column marked by different letters are significantly different within the same group ( $p \leq 0.05$; ANOVA and Tukey-Kramer test). Significant differences between groups are reported as ${ }^{*} p<0.05 ;{ }^{* *} p<0.01 ;{ }^{* * *} p<0.001$. 


\section{Discussion}

In the literature, $\mathrm{NaCl}$ is the most common priming agent [16-18], able to increase seed germination rate in salt-stressed plants. PAs have been also tested; in plant, PA activity is involved in several growth stages and development, as well as in the responses to biotic and abiotic stresses [5,19]. An essential role has been attributed to SPD for the survival of Arabidopsis embryos, whilst SPM plays a role in stress responses [20]. Both SPD and SPM are able to increase transcription of the Betaine aldehyde dehydrogenase 1 (BADH 1) gene, leading to an increased tolerance to salt stress [12].

In our study, we investigated the effects of four different chemical priming solutions on the response to salt of $B$. napus. For this purpose, we selected cultivars with different levels of tolerance, i.e., SY Saveo (sensitive), Edimax CI (moderately tolerant) and Dynastie (tolerant). Meanwhile, different salinity levels of the medium, ranging from non-saline (control) up to very strongly saline [21], were tested, to detect the threshold of tolerance to salt. According to FAO, the salinities used in this work (up to $160 \mathrm{mM} \mathrm{NaCl}$ ) are high, and glycophytes cannot grow well or even do not grow at all under these conditions.

The tested priming agents increased the germination rates of all rapeseed cultivars with respect to the not primed group at the same salinity. $\mathrm{NaCl}$ primed seedlings grew significantly better than not primed at the same salinity, confirming the data of the literature $[22,23]$, but this increase was genotype dependent. Calcium nitrate had a negative effect on plant growth, suggesting an increase in stress, contrarily to the data of Gouveia et al. [24]. Higher growth rates were observed in PA-treated seedlings exposed to stress, confirming literature reports on other species [11,25].

Membranes integrity was affected by the presence of such elevated salinity; nevertheless priming treatments alleviated the symptoms, especially when SPD, SPM and $\mathrm{NaCl}$ were used as chemical agents. These results, in agreement with the literature, suggest a role for PAs in stabilizing cell membranes during salt stress [26].

Controversy exists in the literature regarding the effect of salinity on chlorophyll amount. Generally, a decrease in chlorophyll content caused by salinity has been reported by many researchers $[22,27,28]$. Otherwise, some authors $[29,30]$ affirm that salinity reduces the chlorophyll content in salt-sensitive plants and increases it in salt-tolerant ones. Our data, in the control group, agree with those by Alamgir and Ali [31], which showed an increase in chlorophyll content in rice plants exposed to salt stress. Both PAs increased total chlorophyll content; in particular, SPD priming showed a significant enhancement in all cultivars. Paul and Roychoudhury [12] reported that seed priming with PAs on rice increased the expression levels of RbcS, a gene encoding for RuBisCO. The authors observed that this increase was absent in the not primed plants. This may be a mechanism playing a role also in rapeseed primed with PA.

Since SPD was the most effective priming, showing genotype-independent responses, we decided to further investigate the effects of SPD priming to verify if, after the stimulus, there was a modification in antioxidant responses (i.e., phenolics, SOD activity), PAL activity and osmolyte synthesis (i.e., proline).

To counteract and mitigate the damage caused by the overproduction of ROS, induced by salt stress [32], plants need to increase the presence of active oxygen scavengers (e.g., phenolics, PAs, glutathione, etc.) and the activity of enzymatic protectors (i.e., superoxide dismutase (SOD), catalase (CAT), ascorbate peroxidase (APX) [3,33,34]. In rapeseed, the SPD priming positively influenced the enzymatic and non-enzymatic antioxidant responses. SODs have been described as the first line of defense against ROS, while CAT subsequently detoxifies $\mathrm{H}_{2} \mathrm{O}_{2}$ [35]. Rapeseed seedlings had higher SOD activity because of the salinity exposure; the enzymatic response was even higher in SPD primed plants. Our data confirmed the results obtained by Paul and Roychoudhury [12].

B. napus is a species-rich in phenolic compounds [36], which biosynthesis depends on both genetic and environmental factors, i.e., exposure to stressful conditions, and it is related to the activation of the biosynthetic pathway, which key enzyme is PAL. Our data showed that SPD priming enhanced the activity of PAL, as well as phenolics 
production, in agreement to the reports on salt-stressed and PA-primed rice plants [12] and of Salvia miltiorrhiza Bunge [37].

The synthesis of osmolytes is one of the strategies widely adopted by plants in response to environmental stress $[3,38]$. Proline, besides being one of the osmolytes acting in osmotic adjustment, it can also be a reservoir of both energy and nitrogen to be utilized under stress conditions. Increased proline contents were detected not only upon stress conditions, but also after ABA and PA treatments [39]. SPD seed priming can influence significantly osmotic adjustment by enhancing proline content in a manner related to salinity, in agreement with the results obtained by Sheteiwy et al. [40].

\section{Materials and Methods}

All reagents were analytical grade or equivalent and purchased from Merck or SigmaAldrich, unless otherwise stated. In each set of experiments, all working solutions were prepared immediately before use from stock solutions.

\subsection{Plant Growth Conditions}

The seeds of rapeseed cultivars used in this project were kindly supplied by Dr. Montanari of the CREA-CI (Centro di Ricerca per le Colture Industriali) of Bologna (Italy). The chosen cultivars were " 00 " variety, yielding high amounts of oil while retaining low quantities of erucic acid and glucosinolate. Seeds were stored at $4{ }^{\circ} \mathrm{C}$ until use.

Seed germination tests in saline conditions were undertaken according to Santangeli et al. [5]. The following cultivars were selected based on salt tolerance: SY Saveo (sensitive), Edimax CI (intermediate tolerant) and Dynastie (tolerant).

Priming is a treatment that hydrates the seed in a specific solution; we primed the seeds with the following compounds: spermine (SPM), spermidine (SPD), $\mathrm{NaCl}$ and $\mathrm{Ca}\left(\mathrm{NO}_{3}\right)_{2}$. The best concentrations of priming solutions and time of treatment (Table 7) were selected based on preliminary experiments, during which the seeds were observed in order to prevent radicle emergence. At the end of the treatments, they were rinsed with distilled water and then the hydration treatment was stopped, and the seeds were allowed to air dry at room temperature to reach the original moisture content $(24 \mathrm{~h})$. Primed and not primed seeds were stored and kept at room temperature until the experiments.

Table 7. Chemical priming treatments of the seeds with the different priming solutions.At the end of the treatments, the seeds were dried at room temperature.

\begin{tabular}{cc}
\hline Priming & Treatment (hours) \\
\hline $2.5 \mathrm{mM} \mathrm{SPM}$ & 4 \\
\hline $5 \mathrm{mM} \mathrm{SPD}$ & 3.5 \\
\hline $40 \mathrm{mM} \mathrm{NaCl}$ & 5 \\
\hline $5 \mathrm{mM} \mathrm{Ca}\left(\mathrm{NO}_{3}\right)_{2}$ & 3 \\
\hline
\end{tabular}

After priming treatments, the seeds were surface sterilized ( $70 \%$ ethanol for $5 \mathrm{~min}$, and then soaked in a solution of $1 \% \mathrm{NaClO}$ for $1 \mathrm{~min}$ ) and sown on sterile $1 / 10$ strength Hoagland medium [41] added with $0.5 \%$ agar (Santa Cruz Biotechnology). Thirty-five seeds of each cultivar ( 3 replicates per treatment) were inoculated in glass jars containing $150 \mathrm{~mL}$ of medium $(11 \mathrm{~cm}$ diameter; total capacity $0.5 \mathrm{~L}$ ) and incubated in the dark for $48 \mathrm{~h}$ at $24{ }^{\circ} \mathrm{C}$; they were kept in randomized design until germination was obtained. For salt treatment, $\mathrm{NaCl}$ solutions were added to the medium, obtaining different levels of salinity, measured by electrical conductivity (EC): 0 (controls; not saline EC $=1.92 \mathrm{dS} / \mathrm{m}$ ), $40 \mathrm{mM}$ (moderately saline, EC $=5.04 \mathrm{dS} / \mathrm{m}$ ), $80 \mathrm{mM}$ (strongly saline, EC $=9.16 \mathrm{dS} / \mathrm{m}$ ) and $160 \mathrm{mM}$ (very strongly saline, $\mathrm{EC}=16.89$ ). Experimental groups were divided as follows: (1) not primed seeds (control); (2) not primed seeds exposed to $\mathrm{NaCl}$; (3) primed seeds; (4) primed seeds exposed to $\mathrm{NaCl}$. Germination rates were recorded. 
The plants were grown for 7 days at $23 \pm 2{ }^{\circ} \mathrm{C}$ at constant temperature and $48 \pm 2 \%$ of relative humidity, moved randomly every day, with a photoperiod of $16 / 8 \mathrm{~h}$, PAR $30 \mu$ moles photons $\mathrm{m}^{-2} \mathrm{~s}^{-1}$ (lamp: $2 \times$ OSRAM, FLUORA t8 $36.00 \mathrm{~W}$ and $2 \times$ OSRAM, LUMILUX Cool Daylight t 836.00 W) (Figure 5).

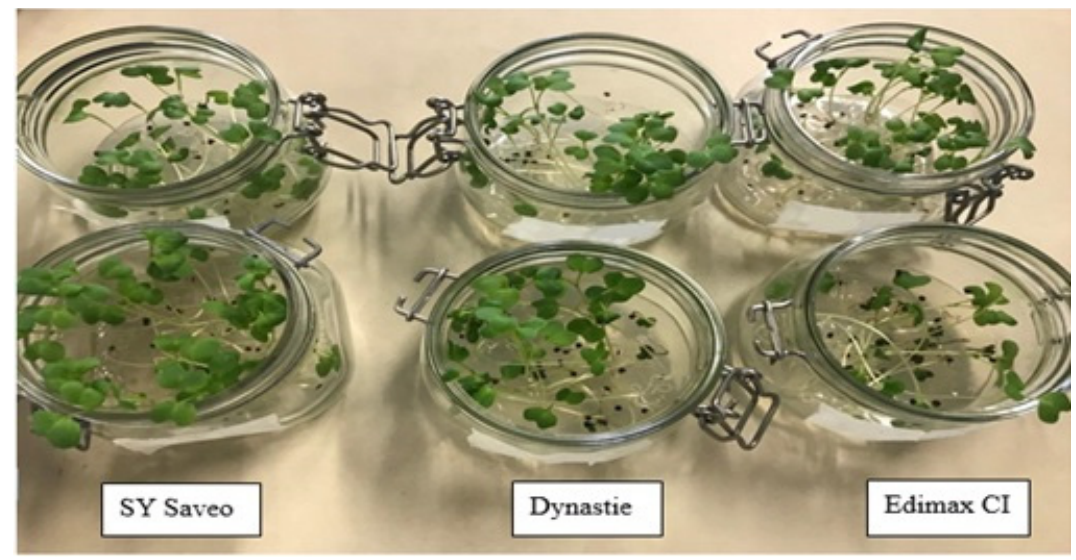

Figure 5. Rapeseed seedlings of the cultivars (Controls below; exposed to $80 \mathrm{mM} \mathrm{NaCl}$ above).

Seedling growth was evaluated by measuring shoot length and longest root length Biomass production was determined in plants immediately weighed after harvesting and used for dry weights measurement [5]. Samples (200 mg FW) were frozen by dipping in liquid nitrogen and stored at $-80^{\circ} \mathrm{C}$ until further analyses.

\subsection{Membrane Injury Index (MII)}

Membrane injury index (MII) was calculated on fresh plant samples by measuring the electrical conductivity (EC) according to Santangeli et al. [5]. Soon after sampling, the seedlings were dipped in milli-Q water in a volume equal to $0.1 \mathrm{~mL} \mathrm{H}_{2} \mathrm{O} \mathrm{mg} \mathrm{FW}{ }^{-1}$. The EC was measured at room temperature with the electrical conductivity meter (Hanna instrument 8333) as follows: after $30 \mathrm{~min}$ sample incubation at $40^{\circ} \mathrm{C}\left(\mathrm{EC} 40^{\circ}\right)$ and then after 10 min sample incubation at $100^{\circ} \mathrm{C}\left(\mathrm{EC} 100^{\circ}\right)$ in a water bath (Gesellschaft für Labortechnik, GFL). MII was calculated following this formula: MII: EC40 / $\mathrm{EC} 100^{\circ *} 100$.

\subsection{Photosynthetic Pigments}

Frozen leaf samples were homogenized with liquid nitrogen using a ceramic mortar and pestle and then dipped in $3 \mathrm{~mL}$ of $95 \%$ ethanol. The homogenates were incubated in the dark, to avoid chlorophyll degradation, at $4{ }^{\circ} \mathrm{C}$ for $1 \mathrm{~h}$, and then centrifugated at $800 \times g$ for $10 \mathrm{~min}$ to remove cell debris. Supernatants were collected and analyzed. To quantify chlorophylls and carotenoids content, the absorbances of the supernatants were measured by a spectrophotometer (Cary 50 Bio. UV-Visible Spectrophotometer) at $664 \mathrm{~nm}$ (chlorophyll a), $648.6 \mathrm{~nm}$ (chlorophyll b) and at $470 \mathrm{~nm}$ (carotenoids).

The concentration of photosynthetic pigments was determined according to Lichtenthaler [42]. The amounts of pigments were expressed as $\mu \mathrm{g} \mathrm{mg} \mathrm{FW}^{-1}$.

\subsection{Determination of the Effects of SPD Priming}

Basing on the results obtained from the screening with the different priming solutions, we selected the most effective, i.e., SPD priming, for further investigation. Analyses were performed in seedlings that were 7 days old.

\subsubsection{Phenolic Compounds}

Frozen seedling samples were homogenized in liquid nitrogen, and phenolic compounds were extracted according to Legrand [43]. Homogenization was conducted in ceramic mortars and pestles at $4{ }^{\circ} \mathrm{C}$, in $3 \mathrm{~mL}$ of $0.1 \mathrm{~N} \mathrm{HCl}$ (Sharlau). The samples were 
incubated for $3 \mathrm{hrs}$ at $4{ }^{\circ} \mathrm{C}$ and then centrifuged for $15 \mathrm{~min}$ at $8000 \times \mathrm{g}$. Supernatants were collected, and the pellets were resuspended in $2 \mathrm{~mL}$ of $0.1 \mathrm{~N} \mathrm{HCl}$ and centrifuged again for $15 \mathrm{~min}$ at $8000 \times \mathrm{g}$. Both supernatants were pooled and brought to a final volume of $6 \mathrm{~mL}$ with an additional $0.1 \mathrm{~N} \mathrm{HCl}$. The total phenolic content was determined by Booker and Miller [44] protocol using Folin-Ciocalteau reagent. Sample absorbance was measured at $724 \mathrm{~nm}$ (VARIAN Cary 50 Bio). The concentration of phenolic compounds was calculated according to a calibration curve of chlorogenic acid (CA) (Alfa Aesar) carried out with solutions of $10 \mu \mathrm{gmL}^{-1}, 20 \mu \mathrm{gmL}^{-1}, 50 \mu \mathrm{gmL}^{-1}, 100 \mu \mathrm{gmL}^{-1}(\mathrm{y}=0.0013 \mathrm{x}-0.0109$; $\mathrm{R}^{2}=0.99$ ). The total phenolic content was calculated as $\mu \mathrm{g}$ chlorogenic acid equivalent $\mathrm{gFW}^{-1}$.

\subsubsection{Proline Content}

Proline and total amino acids were extracted using the procedure reported by Santangeli et al. [5]. Seedling samples (50 mg FW) were heated at $55{ }^{\circ} \mathrm{C}$ for $20 \mathrm{~min}$ in $95 \%$ ethanol. After heating, $500 \mu \mathrm{L}$ of extract was added to $1 \mathrm{~mL}$ of $1 \%(w / v)$ ninhydrin (2,2-dihydroxyindane-1,3-dione) dissolved in a mixture of $60 \%(v / v)$ acetic acid (Fluka) and $20 \%(v / v)$ ethanol (Fluka); the reaction mixture was protected from the light and heated again at $95{ }^{\circ} \mathrm{C}$ for $20 \mathrm{~min}$. The samples were centrifuged for $1 \mathrm{~min}$ at $7000 \times \mathrm{g}$, and the supernatant was collected for proline detection. The absorbance was measured at $520 \mathrm{~nm}$ using the spectrophotometer (VARIAN Cary 50 Bio). Proline concentration was determined from a standard curve made with solutions of L-proline ranging from 0.1 to $1 \mathrm{mM}$ $\left(y=0.0104 x+0.0294 ; R^{2}=0.99\right)$. Data are expressed as nmoles proline $\mathrm{mg} \mathrm{FW}^{-1}$.

\subsubsection{Determination of Enzymatic Activities}

The enzymatic activities were determined in extracts from frozen samples (200 mg FW) homogenized with ceramics mortars and pestles. The protein content of the extracts was determined by Bradford method [45]. A calibration curve with bovine serum albumin (BSA) $\left(1.25,2.5,5\right.$ and $\left.10 \mu \mathrm{g} \mathrm{mL}^{-1}\right)\left(\mathrm{y}=0.0468 \mathrm{x}-0.021 ; \mathrm{R}^{2}=0.998\right)$ was used to determine the total protein concentration. Phenylalanine ammonia-lyase (PAL, EC 4.3.1.24) was extracted according to the method described by Corsi et al. [46]. Briefly, samples were homogenized in $1 \%$ Polyvinylpolypyrrolidone (PVPP) to precipitate the phenolic compounds. The homogenates were re-suspended in $5 \mathrm{~mL}$ acetone $80 \%$ and $5 \mathrm{mM} \beta$-mercaptoethanol and then centrifuged for $10 \mathrm{~min}$ at $3000 \times g$ at $4{ }^{\circ} \mathrm{C}$. The pellets were totally dried under vacuum (Savant), and then suspended in $3 \mathrm{~mL}$ of $50 \mathrm{mM}$ sodium-borate buffer ( $\mathrm{pH} 8.8$ ) and centrifuged at $3000 \times g$ for $10 \mathrm{~min}$ at $4{ }^{\circ} \mathrm{C}$. The reaction mixture $(3 \mathrm{~mL})$, composed by $1.2 \mu \mathrm{M}$ L-phenylalanine in $0.05 \mathrm{M}$ sodium-borate buffer ( $\mathrm{pH} 8.8$ ) and crude extract, was incubated at room temperature for $1 \mathrm{~h}$. Enzymatic reaction was stopped by adding $25 \%$ $(w / v)$ trichloroacetic acid. The absorbance of supernatant was detected at $290 \mathrm{~nm}$. The enzymatic assay was performed using a calibration curve $\left(y=0.1621 x+0.1426 ; R^{2}=0.996\right)$ of trans-cinnamic acid as standard. The enzyme activity was expressed as $\mu \mathrm{g} t$-cinnamic acid $\min ^{-1} \mu \mathrm{g}$ protein ${ }^{-1}$.

Superoxide dismutase (SOD) (EC 1.15.1.1) activity was determined in extracts from frozen leaves (200 mg FW) by NPAGE (native polyacrylamide gel electrophoresis) according to Santangeli et al. [5]. Samples (40 $\mu$ g proteins) were loaded on native polyacrylamide gel electrophoresis. SOD activity was detected according to Beauchamp and Fridovich [47] and was expressed as Arbitrary Units (A.U.) that correspond to the pixel density of each lane obtained by the program ImageJ.

\subsection{Statistical Analysis}

Data are expressed as mean \pm standard error (SE). One-way analysis of variance (ANOVA) was performed with Past 7.0. The Tukey-Kramer method was used to assess the difference of significance among groups. All analyses were considered significant at $p \leq 0.05$ within each treatment group. When comparing inoculated groups with noninoculated ones, the significance was ${ }^{* * *} p<0.001 ;{ }^{* *} p<0.01$; $^{*} p<0.05$. 


\title{
5. Conclusions
}

In rapeseed, seed priming can be a tool to increase salt tolerance, ensuring significant enhancement of plant fitness. The positive effect of SPD priming was genotype independent and was observed even at high soil salinity. Different biochemical strategies are adopted by rapeseed primed with SPD to mitigate the negative effects of salt stress. Overall, the data provide compelling evidence to confirm that priming can be very effective to promote crop establishment and survival in saline conditions, thus deserving further study.

Author Contributions: Conceptualization, C.F., S.B.; methodology, M.R., P.M.S., C.C., C.F.; formal analysis and investigation, P.M.S., M.R., I.B., C.C.; data curation, P.M.S., M.R., C.C., C.F.; software, P.M.S., M.R.; writing—original draft preparation, P.M.S., M.R., C.F.; writing—review and editing M.R., C.C., S.B., C.F.; supervision, C.F. All authors have read and agreed to the published version of the manuscript.

Funding: This research received no external funding.

Institutional Review Board Statement: Not applicable.

Informed Consent Statement: Not applicable.

Data Availability Statement: All data presented in this study are available in the article.

Acknowledgments: We thank Montanari (CREA-CI) for providing seeds.

Conflicts of Interest: The authors declare no conflict of interest.

\begin{abstract}
Abbreviations
fresh weight (FW); spermidine (SPD); spermine (SPM); polyamines (PAs); phenylalanine ammonia lyase (PAL); superoxide dismutase (SOD).
\end{abstract}

\section{References}

1. Khan, F.Z.; Rehman, S.U.; Abid, M.A.; Malik, W.; Hanif, C.M.; Bilal, M.; Qanmber, G.; Latif, A.; Ashraf, J.; Farhan, U. Exploitation of germplasm for plant yield improvement in cotton (Gossypium hirsutum L.). J. Green Physiol. Genet. Genom. 2015, 1, 1-10.

2. Chaves, M.M.; Flexas, J.; Pinheiro, C. Photosynthesis under drought and salt stress: Regulation mechanisms from whole plant to cell. Ann. Bot. 2009, 103, 551-560. [CrossRef] [PubMed]

3. Forni, C.; Duca, D.; Glick, B.R. Mechanism of plant response to salt and drought stress and their alteration by rhizobacteria. Plant Soil 2017, 410, 335-356. [CrossRef]

4. Dizge, N.; Keskinler, B. Enzymatic production of biodiesel from canola oil using immobilized lipase. Biomass Bioenergy 2008, 32, 1274-1278. [CrossRef]

5. Santangeli, M.; Capo, C.; Beninati, S.; Pietrini, F.; Forni, C. Gradual exposure to salinity improves tolerance to salt stress in rapeseed (Brassica napus L.). Water 2019, 11, 1667. [CrossRef]

6. Schwachtje, J.; Whitcomb, S.J.; Firmino, A.A.P.; Zuther, E.; Hincha, D.K.; Kopka, J. Induced, imprinted, and primed responses to changing environments: Does metabolism store and process information? Front. Plant Sci. 2019, 10, 106. [CrossRef]

7. Ilangumaran, G.; Smith, D.L. Plant Growth Promoting Rhizobacteria in amelioration of salinity stress: A systems biology perspective. Front. Plant Sci. 2017, 8, 1768. [CrossRef] [PubMed]

8. Stassinos, P.M.; Rossi, M.; Borromeo, I.; Capo, C.; Beninati, S.; Forni, C. Amelioration of salt stress tolerance in rapeseed (Brassica napus) cultivars by seed inoculation with Arthrobacter globiformis. Plant Biosyst. 2021. [CrossRef]

9. Chen, K.; Arora, R. Priming memory invokes seed stress-tolerance. Environ. Exp. Bot. 2013, 94, 33-45. [CrossRef]

10. Giordano, M.; Pannico, A.; Cirillo, C.; Fascella, G.; El-Nakhel, C.; De Pascale, S.; Rouphael, Y. Influence of priming methods on seed germinability and transplants performance in six vegetable species. Acta Hortic. 2020, 1296, 297-304. [CrossRef]

11. Afzal, I.; Basra, S.M.A.; Farooq, M.; Nawaz, A. Alleviation of Salinity Stress in Spring Wheat by Hormonal Priming with ABA, Salicylic Acid and Ascorbic Acid. Int. J. Agric. Biol. 2006, 8, 23-28.

12. Paul, S.; Roychoudhury, A. Seed priming with spermine and spermidine regulates the expression of diverse groups of abiotic stress-responsive genes during salinity stress in the seedlings of indica rice varieties. Plant Gene 2017, 11, 124-132. [CrossRef]

13. Hilker, M.; Schwachtje, J.; Baier, M.; Balazadeh, S.; Bäurle, I.; Geiselhardt, S.; Hincha, D.K.; Kunze, R.; Mueller-Roeber, B.; Rillig, M.C. Priming and memory of stress responses in organisms lacking a nervous system. Biol. Rev. 2015, 91, 1118-1133. [CrossRef]

14. Antoniou, C.; Savvides, A.; Christou, A.; Fotopoulos, V. Unravelling chemical priming machinery in plants: The role of reactive oxygen-nitrogen-sulfur species in abiotic stress tolerance enhancement. Curr. Opin. Plant Biol. 2016, 33, 101-107. [CrossRef] [PubMed] 
15. Kubala, S.; Wojtyla, Ł.; Quinet, M.; Lechowska, K.; Lutts, S.; Garnczarska, M. Enhanced expression of the proline synthesis gene P5CSA in relation to seed osmopriming improvement of Brassica napus germination under salinity stress. J. Plant Physiol. 2015, 183, 1-12. [CrossRef]

16. Abdollahi, F.; Jafari, L. Effect of $\mathrm{NaCl}$ and $\mathrm{KNO}_{3}$ priming on seed germination of canola (Brassica napus L.) under salinity conditions. Int. J. Agric. Res. Rev. 2012, 2, 573-579.

17. Smith, P.T.; Cobb, B.G. Physiological and enzymatic activity of pepper seeds (Capsicum annuum L.) during priming. Physiol. Plant. 1991, 82, 433-439. [CrossRef]

18. Passam, H.C.; Kakouriotis, D. The effects of osmoconditioning on the germination, emergence and early plant growth of cucumber under saline conditions. Sci. Hortic. 1994, 57, 233-240. [CrossRef]

19. Kumar, A.; Altabella, T.; Taylor, M.; Tiburcio, A.F. Recent advances in polyamine research. Trends Plant Sci. 1997, 2, 124-130. [CrossRef]

20. Takahashi, T.; Kakehi, J.-I. Polyamines: Ubiquitous polycations with unique roles in growth and stress responses. Ann. Bot. 2010, 105, 1-6. [CrossRef]

21. Abrol, I.P.; Yadav, J.S.P.; Massoud, F.I. Salt Affected Soils and Their Management; FAO Soils Bullettin 39; FAO: Rome, Italy, 1988; ISBN 92-5-102686-6.

22. Khan, H.A.; Ayub, C.M.; Pervez, M.A.; Bilal, R.M.; Shahid, M.A.; Ziaf, K. Effect of seed priming with $\mathrm{NaCl}$ on salinity tolerance of hot pepper (Capsicum annuum L.) at seedling stage. Soil Environ. 2009, 28, 81-87.

23. Soughir, M.; Elouaer, M.A.; Hannachi, C. The Effect of $\mathrm{NaCl}$ priming on emergence, growth and yield of fenugreek under saline conditions. Cercet. Agron. Mold. 2013, 46, 73-83. [CrossRef]

24. Gouveia, G.C.C.; Binotti, F.F.D.S.; Costa, E. Priming effect on the physiological potential of maize seeds under abiotic stress. Pesqui. Agropecu. Trop. 2017, 47, 328-335. [CrossRef]

25. Farooq, M.; Basra, S.M.A.; Rehman, H.; Hussain, M. Seed priming with polyamines improves the germination and early seedling growth in fine rice. J. New Seeds 2008, 9, 145-155. [CrossRef]

26. Saha, J.; Giri, K. Molecular phylogenomic study and the role of exogenous spermidine in the metabolic adjustment of endogenous polyamine in two rice cultivars under salt stress. Gene 2017, 609, 88-103. [CrossRef] [PubMed]

27. Ashraf, M.Y.; Akhtar, K.; Sarwar, G.; Ashraf, M. Role of rooting system in salt tolerance potential of different guar accessions. Agron. Sustain. Dev. 2005, 25, 243-249. [CrossRef]

28. Srivastava, T.P.; Gupta, S.C.; Lal, P.; Muralia, P.N.; Kumar, A. Effect of salt stress on physiological and biochemical parameters of wheat. Ann. Arid Zone 1998, 27, 197-204.

29. Hasan, A.; Hafiz, H.R.; Siddiqui, N.; Khatun, M.; Islam, R.; Mamun, A.A. Evaluation of wheat genotypes for salt tolerance based on some physiological traits. J. Crop Sci. Biotechnol. 2015, 18, 333-340. [CrossRef]

30. Ayyub, C.; Rashid Shaheen, M.; Raza, S.; Sarwar Yaqoob, M.; Khan Qadri, R.; Azam, M.; Ghani, M.; Khan, I.; Akhtar, N. Evaluation of different radish (Raphanus sativus) genotypes under different saline regimes. Am. J. Plant Sci. 2016, 7, 894-898. [CrossRef]

31. Alamgir, A.N.M.; Yousuf Ali, M. Effect of salinity on leaf pigments, sugar and protein concentrations and chloroplast ATPase activity of rice (Oryza sativa L.). Bangladesh J. Bot. 1999, 28, 145-149.

32. Gill, S.S.; Tuteja, N. Reactive oxygen species and antioxidant machinery in abiotic stress tolerance in crop plants. Plant Physiol. Biochem. 2010, 48, 909-930. [CrossRef] [PubMed]

33. Munns, R.; Tester, M. Mechanism of salinity tolerance. Ann. Rev. Plant Biol. 2008, 59, 651-681. [CrossRef] [PubMed]

34. Lim, J.H.; Park, K.J.; Kim, B.K.; Jeong, J.W.; Kim, H.J. Effect of salinity stress on phenolic compounds and carotenoids in buckwheat (Fagopyrum esculentum M.) sprout. Food Chem. 2012, 135, 1065-1070. [CrossRef]

35. Krasensky, J.; Jonak, C. Drought, salt, and temperature stress-induced metabolic rearrangements and regulatory networks. J. Exp. Bot. 2012, 63, 1593-1608. [CrossRef] [PubMed]

36. Cartea, M.E.; Francisco, M.; Soengas, P.; Velasco, P. Phenolic compounds in Brassica vegetables. Molecules 2011, 16, 251-280. [CrossRef]

37. Hao, G.; Ji, H.; Li, Y.; Shi, R.; Wang, J.; Feng, L.; Huang, L. Exogenous ABA and polyamines enhanced salvianolic acids contents in hairy root cultures of Salvia miltiorrhiza Bunge. f. alba. Plant Omics 2012, 5, 446-452.

38. Deinlein, U.; Stephan, A.B.; Horie, T.; Luo, W.; Xu, G.; Schroeder, J.I. Plant salt-tolerance mechanisms. Trends Plant Sci. 2014, 1145, 1-9. [CrossRef] [PubMed]

39. Pál, M.; Tajti, J.; Szalai, G.; Peeva, V.; Végh, B.; Janda, T. Interaction of polyamines, abscisic acid and proline under osmotic stress in the leaves of wheat plants. Sci. Rep. 2018, 8, 12839. [CrossRef]

40. Sheteiwy, M.; Shen, H.; Xu, J.; Guan, Y.; Song, W.; Hu, J. Seed polyamines metabolism induced by seed priming with spermidine and 5-aminolevulinic acid for chilling tolerance improvement in rice (Oryza sativa L.) seedlings. Environ. Exp. Bot. 2017, 137, 58-72. [CrossRef]

41. Hoagland, D.R.; Arnon, D.I. The water-culture method for growing plants without soil. Circ. Calif. Agric. Exp. Stn. 1950, $347,32$.

42. Lichtenthaler, H.K. Chlorophylls and carotenoids: Pigment of photosynthetic biomembranes. Methods Enzymol. 1987, 148, 350-382.

43. Legrand, B. Action de la lumière sur les peroxydases et sur la teneur en composes phénoliques de tissus de feuilles de Chichorium intybus L. cultivés in vitro. Biol. Plant. 1977, 19, 27-33. [CrossRef]

44. Booker, F.; Miller, J. Phenylpropanoid metabolism and phenolic composition of soybean [Glycine max (L.) Merr.] leaves following exposure to ozone. J. Exp. Bot. 1998, 49, 1191-1202. [CrossRef] 
45. Bradford, M.M. A rapid and sensitive method for the quantitation of microgram quantities of protein utilizing the principle of protein-dye binding. Anal. Biochem. 1976, 72, 248-254. [CrossRef]

46. Corsi, B.; Riccioni, L.; Forni, C. In vitro cultures of Actinidia deliciosa (A. Chev) C.F. Liang \& A.R. Ferguson: A tool to study the SAR induction of chitosan treatment. Org. Agric. 2015, 5, 189-198. [CrossRef]

47. Beauchamp, C.; Fridovich, I. Superoxide dismutase: Improved assays and an assay applicable to acrylamide gels. Anal. Biochem. 1971, 44, 276-287. [CrossRef] 